\title{
CHANGING THE CORPORATE CULTURE: A KNOWLEDGE MANAGEMENT TECHNOLOGY STUDY IN THREE PHASES
}

\author{
Debra J. Borkovich, Robert Morris University, borkovich@rmu.edu
}

\begin{abstract}
This research paper explored one small U.S. entrepreneurial technology company's struggles and successes to incorporate Knowledge Management (KM) techniques to further its business goals, strategies, and competitive advantage. This case study is the story of Techbot, and its experiences and challenges through three phases of KM implementation: 1). Strengths, Weaknesses, Opportunities, and Threats (SWOT) analysis; 2). Knowledge (K) Audit; and the 3). System Blueprint and Project Implementation. The initial KM implementation, findings, and resultant discussion disclosed that although Techbot was predictable in certain KM outcomes for a small entrepreneurial group, organizational culture coupled with conflict resolution and change management played larger roles in successful KM integration than either the organization's senior management or the researcher anticipated. This finding further confirmed other subject matter experts' arguments that 'corporate culture' deserved equal standing and consideration among 'people, processes, and technology' as the bedrock of a well-executed KM project.
\end{abstract}

Keywords: Knowledge Management, Corporate Culture, Tacit and Explicit Knowledge, Technology SWOT, Knowledge Audit, System Blueprint and Implementation

\section{INTRODUCTION}

This research paper focused on one small entrepreneurial U.S. technology company and its struggles and successes to incorporate Knowledge Management (KM) techniques to further its business goals, strategies, and competitive advantage in its support of U.S. Federal Government research and development programs. This qualitative case study is the story of Techbot (a pseudonym used to protect the company's anonymity), as told by the embedded researcher who implemented a KM process to explore the viability of the company's Information System (IS). The overarching objective was to ascertain its effectiveness, identify areas for improvement, and if needs dictated, ensure that Techbot had a safe, secure, user-friendly efficient environment to electronically post, store, maintain, access, collaborate, and share information. The researcher also performed the lead role of auditor through three phases of KM implementation: 1). Strengths, Weaknesses, Opportunities, and Threats (SWOT) analysis; 2). Knowledge (K) Audit; and the 3). System Blueprint and Project Implementation. The data collection, analysis, findings and resultant discussion disclosed that Techbot was very predictable in certain KM outcomes for a small entrepreneurial group; however, organizational culture coupled with conflict and change management played larger roles in successful KM implementation than either the organization's senior management or the researcher anticipated. Although the initial KM results were favorable, findings indicated that the intangible 'soft' social science of corporate culture that influenced organizational behavior required a greater understanding by both management and professionals in order to secure long-term employee buy-in to the new technology system and acceptance of KM as an integral corporate construct and strategic partner. Research results further confirmed other subject matter experts' arguments that corporate culture deserved equal standing and consideration among 'people, processes, and technology' as the bedrock of a well-executed KM project.

\section{LITERATURE REVIEW}

\section{Knowledge (K), Knowledge Management (KM), and Knowledge Audit (KA)}

Nonaka [26; 27] philosophized that two types of knowledge existed: 1. Explicit (rational, objective, context-free, and memorialized in some fashion); and, 2. Tacit (subjective, linked to mental schemas, highly contexualized and experiential). Furthermore, Nonaka and Konno [28] theorized that knowledge creation required a "ba," an existential framework or place (physical, mental, or virtual) to survive and flourish. Polanyi [31;32] proffered the "structure of tacit knowing," arguing that all knowledge relies on personal judgments in which "we believe more than we can prove and know more than we can say." 


\section{Issues in Information Systems}

Subject matter experts offered a plethora of definitions and insights relevant to KM. Tiwana [35, p. 333] argued that KM's primary purpose was "the creation, collection, and conversion of individual knowledge into organizational knowledge," and expanding core competencies with technological innovation and collaborative integration by implementing the three basic processes of KM: 1). Knowledge Acquisition, 2). Knowledge Sharing, and 3). Knowledge Utilization [35, p. 50]. O'Dell and Hubert [29, p. 2] preferred a more pragmatic approach that defined knowledge management "as a systematic effort to enable information and knowledge to grow, flow, and create value ... as information in action."

"Knowledge audits are considered as the first critical step for implementing knowledge management (KM) practices in organizations" [16, p. 11]. "It also contributes toward establishing a KM strategy for the organization" [19, p. 40]. A critical KM path is identifying and converting critical tacit knowledge to explicit information by leveraging existing tools and resources or incorporating new processes and technologies. Other critical needs of a KM audit include business and cultural assessments, and an examination of what knowledge is needed, available, missing, and currently implemented within an organization. "KM audits provide insights into current KM practices by means of a 'snapshot'.... [However] An organization's culture must be understood before a KM solution can be implemented successfully" [16, p. 117]. Liebowitz [19, p. 49] argued that: "The outcome of the knowledge audit ... will give a sense of the organizational culture and climate that will help to best match a KM approach and project with the organization's needs and culture." Knowledge, unlike raw data and organized information, is created and processed in the human brain; is based upon experience, context, interpretation, reflection, incidental memory, random factoids, and at times, even intuition; is critical to organizational and personal success; therefore, it needs to be managed.

\section{KM and Corporate Culture}

A corporate culture based upon openness, trust, respect, collaboration, mentoring, incentives, and rewards are often necessary to ensure an organizational climate of knowledge sharing. Researchers consistently articulated that organizational culture is inured and employees tend to embrace information systems that are in concert with their culture and resist those that conflict with their culture [2]. Tiwana [35, p. 294] argued that the success of creating a culture of knowledge sharing hinges upon changing "corporate culture from that of defensive knowledge hoarding to a knowledge-sharing one." However, a knowledge-friendly culture is difficult to create if one does not already exist. Metaphorically, Davenport, DeLong, and Beers [4, p. 53] expressed: "If the cultural soil isn't fertile for a knowledge project, no amount of technology, knowledge content, or good project management practices will make the effort successful." Unlike data, "knowledge is created invisibly in the human brain, and only the right organizational climate can persuade people to create, reveal, share and use it" [4, p. 56].

\section{KM Case Studies}

O'Dell and Hubert [29] cited large business case studies at ConocoPhillips, Fluor, IBM, and MITRE as benchmarks for successful KM implementation to fit specific cultures and business models. For example, ConocoPhillips global enterprise of 30,000 employees in 30 countries deployed a KM strategy to establish knowledge sharing and collaboration with teams, forums, libraries, and wiki through a family of $\mathrm{MS}^{\circledR}$ SharePoint ${ }^{\circledR}$-based network portal sites during a six-month period in 2009. "Building a collaborative culture ... changing the mindset of employees ... and cultivat[ing] online trust" [29, pp. 168-169] was imperative to encourage and foster intra-community collaboration.

Davenport [4] and his team studied $31 \mathrm{KM}$ projects (in various stages of development) within 24 companies via telephonic interviews and four on-site visits to learn how organizations use knowledge effectively. The authors [4, $\mathrm{p}$. 56] determined that "effective KM is neither panacea nor bromide. . . [W] [hen a business faces competitors that perform well on those other dimensions, the difference between success and failure may well run on how effectively it manages its knowledge."

Liebowitz [18, p. 254] presented a KM strategy and implementation plan for a U.S. Government technical organization "to best leverage knowledge internally and externally." Critical to this case study was the goal to 


\section{Issues in Information Systems}

support the Government's human capital strategy by capturing the knowledge and skills of retiring employees and the changing digital and social workplace behaviors of younger generations.

Interested in the role national culture played in KM implementation, Gloet's [10] case study of 26 Australian and 31 Hong Kong junior and mid-level managers implemented surveys and focus groups to reveal the understandings managers had about KM practices and whether or not implementation would be feasible in their companies. Surprisingly, results revealed that $45 \%$ had no idea if their respective companies had a KM program; and therefore many could not articulate a KM definition or communicate if their companies were predisposed to accept a KM program. From the national culture perspectives of Hofstede, Hofstede, and Minkov [14] and Hall [11], it was further revealed that Australia, a low context culture, was predisposed to a more explicit form of knowledge; and Hong Kong, a high context culture, was more comfortable with tacit knowledge.

Although KM case studies for large global businesses, academic institutions, and Government agencies abound, this author could not identify a qualitative published KM study case (based upon personalized interviews and observations) for a small U.S. entrepreneurial technology firm with which to compare or transfer the current research. However, prior organizational studies gave credence to the importance, influence, and impact KM had on competitive intelligence and knowledge-based service-driven organizations resulting in successful business strategies. Therefore, it was determined that assessing the feasibility and implementation of a KM program within a nascent organizational business structure founded upon knowledge-based technology services would bring a new dimension filtered through the lens and worldview of a fledgling entrepreneurial company.

\section{RESEARCH METHODOLOGY}

The qualitative methodology of case study research was selected for this project as the preferred strategy to address the exploratory questions of how or why "when the focus is on a contemporary phenomenon within some real-life context" [38, p. 1]. Case studies generally do not require long extended periods of field work, such as ethnographies, so due to a short-term research performance period of six weeks, an agile, fluid, adaptive, yare approach to inquiry was required to implement direct observations and interviews. The term agile (in this context) emanated from Larman's [15] information systems development methodology meaning rapid and flexible response to change, maneuverability, and iteration. Therefore, this descriptive case study was designed to focus on direct observations of events and interviews of persons involved by posing the following research questions (RQ):

RQ1: How does a small entrepreneurial technology firm of subject matter experts (SME) efficiently implement a cost-effective influential KM Program?

RQ2: Why were these KM measures taken, certain decisions made, and what was the result?

Readers are directed to the $\mathrm{K}$ Audit Phase for an explicit and specific representation of methodology deployment.

\section{TECHNOLOGY ROBOTICS CORPORATION}

Technology Robotics Corporation ("Techbot") is a Mid-Atlantic U.S. corporation, whose primary mission is to serve the U.S. Federal Government ("Government") as a prime contractor. Techbot's annual revenue is approximately $\$ 8.6 \mathrm{M}$ and its labor base is comprised of twenty-two employees consisting of a President, Chief Security Officer (CSO), Controller, Program Manager, Contracts Manager, Information Technology Manager, eleven Engineers, and five technicians who perform research and development services for the U.S. military; therefore IS/IT capability and security is of paramount importance to the well-being of the company, its customers, and the nation. To further complicate the care and custody issues of creating, securing, storing, accessing, and retrieval of corporate and customer documents, management recognized that a vast amount of institutional knowledge was maintained in tacit form and not explicitly documented. Therefore, since Techbot could not rely upon the resources, expertise, and finances of a parent company to assist with and resolve its KM issues, the Contracts Manager, a newly hired employee with no pre-existing history of Techbot and a zero to negligible bias, served as both researcher and auditor. This research was performed in three phases beginning with the SWOT technology analysis to ascertain the effectiveness of the current Information Systems (IS) program, identify areas for improvement, and focus immediately on improving one area of primary importance. Liebowitz [19, p. 59] described 


\section{Issues in Information Systems}

this approach as "starting small with a modest goal" by identifying an initial KM initiative or "low-hanging fruit [to meet] the greatest short-term need in the organization where KM can best be applied."

As espoused in its corporate mission statement, Techbot's corporate philosophy is summarized as: "Talented People, Innovative Technology, Entrepreneurship, Customer Transparency, Commitment, Performance, Quality, and Continuous Improvement." This statement clearly illustrates that knowledge, specifically technology and engineering intelligence, plays an important role in its corporate success. Its business strategy to further technology research and development for the Government customer relies heavily on its internal commitment to efficient quality, reliable implementation of its deliverables, and sustained secure records management and documentation control. According to Nastase, Stoica, Mihau, and Stanciu [25, p. 327], " $80 \%$ of corporate information resides in documents . . . [and only those captured and stored] form a large part of the organizational memory." This theory further aligns Techbot's mission to expand its core competencies with technological innovation and collaborative integration by implementing a KM process to codify tacit knowledge into explicit documentation.

The small intimate framework of Techbot consists of a majority number of professional subject matter expert (SME) employees who primarily charge direct labor to customer projects; operate under a limited overhead (indirect) budget; experience an overall lack of administrative support personnel; rarely coordinate their IT needs; and seldom share information in a collaborative manner, often creating their own 'autonomous' documentation management and control systems. Petrides, McClelland, and Nodine [30, p. 100] suggested that these exogenous employee remedies known as 'workarounds, ' can be both innovative and costly arguing that,

In a challenging information environment, enterprising individuals - when unable to obtain the data they need from existing information systems - compensate by creating, or participating in, idiosyncratic methods of data collection and management. These informal practices called workarounds - can be seen as both inventive solutions to pressing organizational needs, and over time, costly alternatives to a robust and flexible information system.

\section{Corporate KM Project Constraints}

Prior to commencing the KM project, several issues were identified as 'givens;' items that could not be changed by either the corporation or the researcher (auditor). These items were identified as: 1). Corporate Budget: $\$ 50,000$ allocated to implement the solution and provide employee training during the first year; and 2). Researcher's Period of Performance: 6 Weeks Total = 240 Hours; 40 hrs. - Conduct the SWOT: 40 hrs. - Analyze data and draft SWOT report; 40 hrs. - Conduct the K Audit; 40 hrs. - analyze the findings; 40 hrs. - Research the solutions and identify a course of action going forward; and $40 \mathrm{hrs}$. - Develop and deliver the Audit Report to management with a recommended solution. Project roll-out and implementation was limited to a subsequent six-month period. Since the researcher was a then-employee of Techbot, the time (labor) devoted to this project was billed to an IT overhead account and not identified as a direct cost to this project. Figure 1 illustrates the three phases of Techbot's KM initiative.

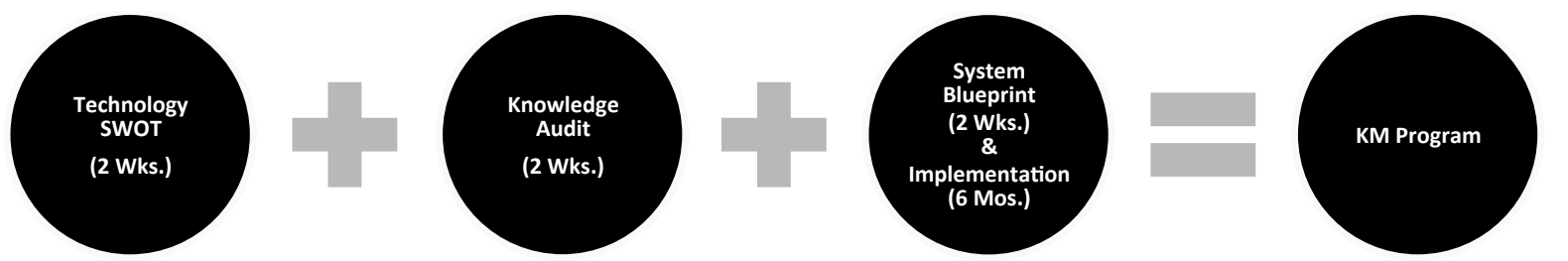

Figure 1. Techbot's Knowledge Management (KM) Initiative - A Three (3) Phased Approach

Due to the researcher's limited period of performance, an agile flexible approach was required to complete the entire project in six weeks. Agility was demanded to capture the dynamic fluid needs of a workplace situation, with the ability to make course corrections rapidly, meeting constant scope and schedule changes, and acting with speed and precision. To ensure the highest level of researcher/auditor performance, distinguishing and understanding what 


\section{Issues in Information Systems}

represented the highest value of time was about adapting one's mindset to evolving priorities while retaining a dominant focus.

\section{PHASE I - THE SWOT ANALYSIS}

A knowledge assessment SWOT analysis of Techbot was performed to explore the causes and effects of its internal strengths and weaknesses and external factors of opportunities and threats identifying the attributes, both beneficial and detrimental, that played significant roles in improving a collaborative KM strategy for the organization. Turban, Sharda, Delen, and King [36, pp. 8-9] asserted that an analytical process focused on informed decision making is "the process of business intelligence, based on the transformation of data to information, then to decisions, and finally to actions." The researcher performed this data gathering through interviews with senior management, the technical and professional staff; the examination of tangible artifacts (i.e., hardware, software, policies, procedures, engineering reports, purchase orders, contracts, memos, and corporate guidance); and direct observations of the employees over a forty-hour workweek.

Four key points were evidenced from the KM technology SWOT: 1). Strengths: Techbot had a high level of tacit SME know-how, intellectual knowledge, and human capital from highly educated talented employees; 2). Weaknesses: Techbot did not have a high level of explicit SME know-how, intellectual knowledge, and documentation (i.e. electronic or hard copy library); and the employees functioned in personal academic technology silos neither sharing knowledge nor collaborating; 3). Opportunities: A small entrepreneurial firm, Techbot could easily implement an innovative KM system with equitable employee input and limited financial investment; and 4). Threats: Failure to implement a KM system would severely limit Techbot's potential to stay viably competitive in its industry; postponing implementation of a KM system would result in a considerable amount of additional time, labor, and increased costs as the company grows in size and complexity; and ignoring the current data-hoarding noncollaborative corporate culture by not capturing tacit information in explicit form could result in torpedoing a project or research initiative with the loss of a single employee. Table 1 illustrates the detailed current attributes (benefits and limitations) resulting from Techbot's knowledge SWOT.

Table 1. Techbot's Knowledge Attributes: SWOT Results

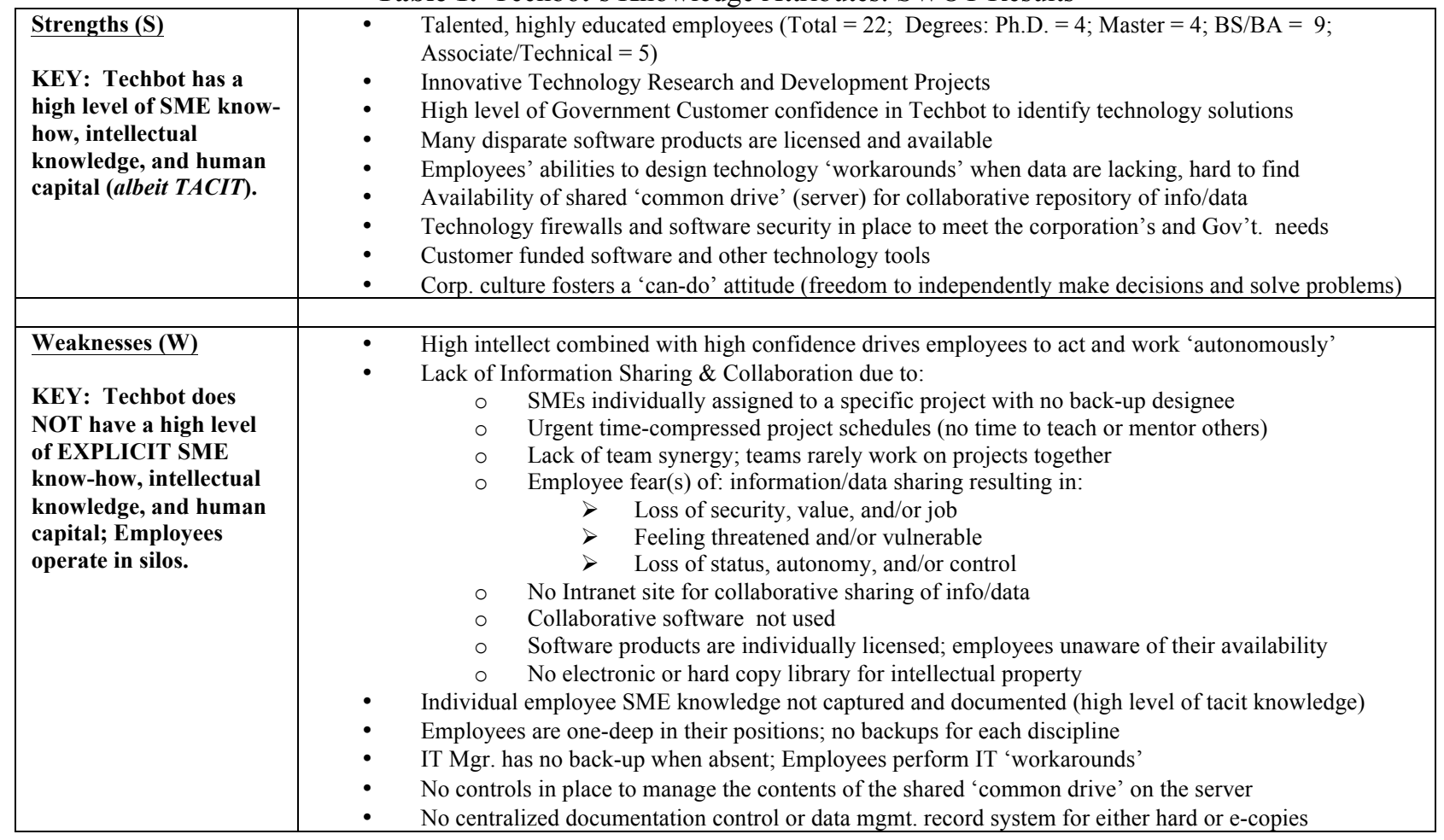




\section{Issues in Information Systems}

Volume 14, Issue 2, pp.233-252, 2013

\begin{tabular}{|c|c|c|}
\hline & & $\begin{array}{l}\text { Each employee is responsible for his/her own data/info } \\
\text { Employees order their own software and tech tools, as needs dictate, without group input } \\
\text { No internal Knowledge Champion, Librarian, or Documentation Control Manager }\end{array}$ \\
\hline $\begin{array}{l}\text { Opportunities (O) } \\
\text { KEY: Techbot is small } \\
\text { in size; able to facilitate } \\
\text { an innovative KM } \\
\text { system with ease and } \\
\text { limited investment; } \\
\text { while concurrently } \\
\text { instilling a collaborative } \\
\text { corporate culture. KM } \\
\text { is needed to stay current } \\
\text { with the competition; } \\
\text { innovation and cutting } \\
\text { edge tech ideas are } \\
\text { needed to be an industry } \\
\text { leader. }\end{array}$ & & 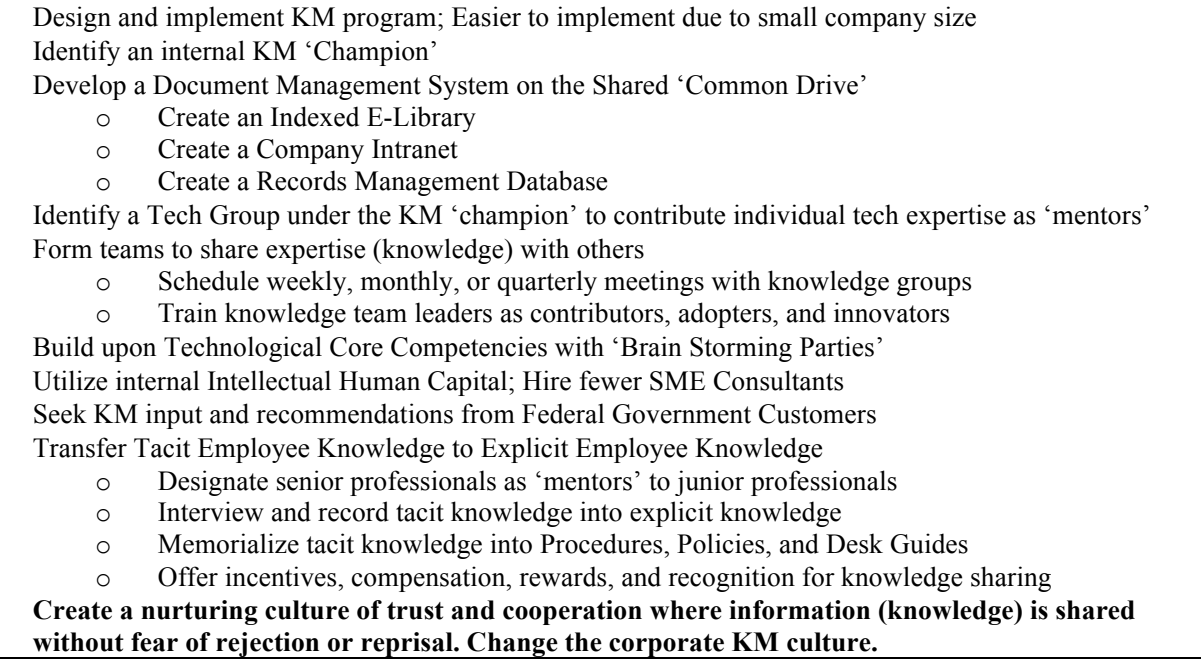 \\
\hline $\begin{array}{l}\text { Threats }(T) \\
\text { KEY: KM is essential } \\
\text { (in most industries) to } \\
\text { keep current with the } \\
\text { competition. Failure to } \\
\text { implement an innovative } \\
\text { KM system and a } \\
\text { collaborative corporate } \\
\text { culture while the } \\
\text { company is small will } \\
\text { result in a considerable } \\
\text { investment of time, } \\
\text { labor, and costs as the } \\
\text { company increases in } \\
\text { size and complexity. }\end{array}$ & & $\begin{array}{l}\text { Loss of customer confidence, credibility, reliability, and dependability if data/info cannot be developed, } \\
\text { identified, located, stored, accessed and retrieved in a timely manner; could result in potential: } \\
\circ \quad \text { Loss of historical expertise due to lack of a documentation control system (indexed library) } \\
\circ \quad \text { Repetitive charges to customers for duplicate work; audits surface costly errors } \\
\circ \quad \text { Loss of recurring and new business through data mismanagement } \\
\text { Potential loss of knowledge, info, data due to lack of centralized repository for customer and company } \\
\text { info and data; each employee is responsible for his/her own documentation control system } \\
\text { Potential loss of tacit knowledge, technology, and intellectual property through loss of SMEs due to: } \\
\circ \quad \text { Retirement, voluntary or involuntary separation, natural attrition } \\
\circ \quad \text { Recruitment of SMEs by competitors } \\
\circ \quad \text { Loss of IT Manager with no back-up designated } \\
\circ \quad \text { Loss of legacy system info and historical data known only to a single SME at any one time } \\
\circ \quad \text { Loss of specific info/data availability on 'common drive' due to loss of a single SME } \\
\text { Inability to pass Federal Government documentation control, management, and security audits if data are } \\
\text { not easily identified, locatable, and accessible } \\
\text { Current Corporate Culture is not dedicated to KM. }\end{array}$ \\
\hline
\end{tabular}

Completion of the initial KM Phase I set the groundwork for further research by describing the organization under study, conceptualizing its knowledge and intellectual attributes in a SWOT exercise; and illustrating that an innovative entrepreneurial approach are often not enough to ensure corporate success, a competitive advantage, and long term viability. While exploring the technical components of its explicit and tacit corporate knowledge, the researcher identified Techbot as one that would benefit from a KM audit during this critical stage in its nascent development, by identifying and targeting a single KM issue of import that required immediate attention. Liebowitz, et al. [20, p. 10] stressed the importance of identifying all knowledge assets in the audit process; and Henczel [13] recommended that an Information Audit be performed prior to the onset of a K Audit. Therefore to aid in this data gathering effort, the SWOT exercise further identified Techbot's technology infrastructure of disparate software (Table 2).

Table 2. Techbot's Technology Infrastructure: Software

\begin{tabular}{|c|c|c|}
\hline Software & Type & Purpose \\
\hline 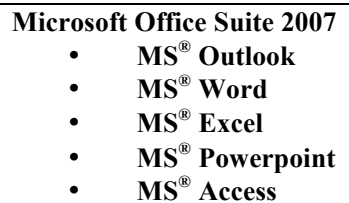 & Desktop Application Software & $\begin{array}{ll}\text { - } & \text { Email } \\
\text { - } & \text { Word Processing } \\
\text { - } & \text { Spreadsheets } \\
\text { - } & \text { Presentations } \\
& \text { Databases }\end{array}$ \\
\hline
\end{tabular}




\section{Issues in Information Systems}

Volume 14, Issue 2, pp.233-252, 2013

\begin{tabular}{|l|l|l|}
\hline Adobe Acrobat 9 Standard & Desktop Application Software & $\begin{array}{l}\text { View, create, manipulate, print and manage } \\
\text { files in Portable Document Format (PDF) }\end{array}$ \\
\hline Windows Power DVD & Desktop Application Software & DVD Maker and Copier \\
\hline MS $^{\circledR}$ Project & Project Management Application Software & $\begin{array}{l}\text { Software develops plans, assigns resources, } \\
\text { tracks progress, manages budgets/schedules }\end{array}$ \\
\hline Primavera $^{\circledR}$ P6 & Project Management Application Software & $\begin{array}{l}\text { Software develops plans, assigns resources, } \\
\text { tracks progress, manages budgets/schedules }\end{array}$ \\
\hline Pro/ENGINEER (Creo Elements/Pro) & Application Software for Engineering Design & Integrated 3D/CAD/CAM/CAE Graphics \\
\hline Perforce Software & Configuration Management Software & Version/Chg. Control; Auditability; Collab. \\
\hline Tortoise SVN & Free Collaborative Software for Windows & Revision/Version/Source Control Software \\
\hline Deltek Costpoint ${ }^{\circledR}$ & $\begin{array}{l}\text { Enterprise Resource Planning Software } \\
\text { Package for Business Application }\end{array}$ & $\begin{array}{l}\text { Finance; Accounting; Purchasing; Inventory } \\
\text { Control Mgmt. }\end{array}$ \\
\hline Deltek Time \& Expense/Self- Service & Business Application Software & Timekeeping; Expense Reports \\
\hline MS ${ }^{\circledR}$ Internet Explorer & Graphical Web Browser (Part of Op. System) & Internet Web Browser \\
\hline MS ${ }^{\circledast}$ Server 2010 & Server Operating System (OS) & Operates Server \\
\hline Barracuda Firewall & Network Application Firewall & Network-based Application Layer Firewall \\
\hline Barracuda Spam Filter & Spam \& Virus Firewall for Enterprises \& ISPs & Spam and Virus Firewall Plug-in Appliance \\
\hline Postini & Email Quarantine Application - Cloud Services & $\begin{array}{l}\text { Email/web security/archiving/filtering spam } \\
\text { \& malware }\end{array}$ \\
\hline $\begin{array}{l}\text { Cisco System Virtual Private Network } \\
\text { (VPN) Client }\end{array}$ & VPN Software & $\begin{array}{l}\text { External remote interface to co. applications; } \\
\text { Enables computers to connect to a VPN }\end{array}$ \\
\hline Voice over Internet Protocol (VoIP) & $\begin{array}{l}\text { Network Transmission Technology for IP } \\
\text { networks }\end{array}$ & $\begin{array}{l}\text { Voice/data communications delivered over a } \\
\text { single network }\end{array}$ \\
\hline MS ${ }^{\circledR}$ Windows XP & Operating System (OS) & Operates PCs; Desktops; Laptops \\
\hline
\end{tabular}

\section{PHASE II - THE KNOWLEDGE (K) AUDIT}

The overarching audit objective was to uncover the current practices (or deficiencies) that have prohibited a successful e-records management and documentation control system to date; to identify the critical user(s) needs for such a system; to assess the findings; and to develop a mutually agreeable cost-effective solution to meet the primary and critical needs for the parties involved. "Record keeping is at the heart of these 'data cultures' and effective data management is essential to their success" [6, p. 3].

\section{The Problem(s) and the Goal}

The SWOT exercise performed in Phase I identified a number of technology and culture-driven weaknesses at Techbot; however, the weaknesses collectively appeared to point to an overall lack of electronic (e-) record management and documentation control. Additionally, a lack of K collaboration and sharing was a major factor due to the lack or unavailability of information when it was needed, further contributing to the corporate culture of information hoarding, personal silos, tacit knowledge, and the need for individual data control.

Therefore, the primary goal of this exercise was to ensure that Techbot had a safe, secure, user-friendly efficient environment to electronically post, store, maintain, access, collaborate, and share information. The objective of this Phase II Knowledge Audit was two-part: 1). Determine if Techbot's 'informal' e-records management and documentation system on the common drive was sufficient for the employees need for knowledge; and if not, why not? And, 2). Determine if the need for a 'formal' e-records management and documentation control system implementation was warranted. Over a two week period, the K Audit assessed the problems and deficiencies of the company's current documentation system, and the need for a comprehensive e-documentation library to capture, maintain, store, access, transfer, collaborate and share explicit knowledge. Furthermore, the corporate culture was examined to identify the reasons, if any, for the lack of knowledge collaboration, sharing, and mutual availability.

\section{The Ideal State - Nirvana}

Corporate management expected a cost-effective, time sensitive, easily facilitated and maintained, accessible and efficient KM solution to meet its record management and documentation control issue. Therefore, the best case scenario was to produce $\mathrm{K}$ audit results within the time and budget constraints previously identified; resolve the identified problems and weaknesses with a technology solution that was not too complex nor too difficult to implement quickly and efficiently; require only a minimal amount of user training that ensured employee buy-in to 


\section{Issues in Information Systems}

the solution (and therefore system usability without too much push-back); require little maintenance, few upgrades, and minimal IT oversight; and one that met the needs of the company, the employees, and its customers to the maximum practicable extent. A truly ideal KM technology solution, a 'Nirvana,' would be one that all employees readily welcomed, embraced, and used instinctively and intuitively, a genuine change in the KM culture of Techbot. "An organization's culture must be understood before a KM solution can be implemented successfully" [16, p. 117].

\section{Audit Methodology}

Due to the small number of Techbot employees (22), the researcher performed the audit as a qualitative approach to inquiry by conducting personnel interviews of the entire population; and not deploying the traditional quantitative survey instrument generally implemented in large organizations depicting a sample size. The audit tool of individual one-on-one interviews (approximately 1 to 1.5 hour in length) were scheduled with each officer and manager, the lead engineer of each discipline, and then with the remaining engineers in groups of three. The only exception to individual or three-person interviews was a group interview held with the five technicians since they freely admitted during Phase I that their use of the common drive to post or access information, including email, was occasional. The interview protocol was based upon fourteen semi-structured questions that focused on the KM activities relative to the process and control of documentation, record-keeping, access, collaboration, sharing of information, version control, and the overall corporate KM culture.

Due to the number of employees interviewed (21) and the time and budget constraints imposed, a software program was not utilized to analyze the data. Instead, the interview data were transcribed from journal field notes of thick description and typed onto a MS ${ }^{\mathrm{TM}}$ Excel spreadsheet for thematic analysis of the responses (i.e. sorting, collating, naming categories, and identifying patterns and trends). Rigorous analysis was performed by cross-checking responses through iterative review of member checks, follow-up confirmations, and examination of electronic and hard copy documentation. The Contracts Manager (also the researcher), a new employee with few preconceived notions of Techbot's documentation process, little history of the organization, and zero to minimal bias relative to the current system, recused herself as a potential interviewee, and assumed the role of auditor, as well.

\section{Audit Process}

The audit process was conducted in four stages. The first stage was a series of employee interviews to learn about the current KM processes that take place in the organization and the employees' expectations for a new recordkeeping and documentation control system. Specifically, individual KM user needs for the development, storage (maintenance), access (transfer), and sharing (collaboration) of documentation were addressed and opinions solicited. The second stage was the auditor's review of the interview notes, identifying common threads and consistent elements of the discussions (i.e. concerns, problems, issues, areas of interest, perceptions, etc.), and noting specific items for follow-up. Stage three included a second round of discussions with all the interviewees to request clarifications and confirmation of certain data; to ask the respondents for any new information or ideas they wanted to introduce or if they had any questions for the auditor; and lastly to focus on each employee's perception of the current corporate KM culture. Stage four covered the auditor's transcription, thematic review, identification of patterns, categorization of trends, data analysis, findings, and preparation of the written report.

The SWOT analysis collected adequate data on the existing documentation system, the current record-keeping process, collaboration, sharing practices of the employees, and background information regarding the current KM corporate culture. Based upon the Phase I SWOT data and the accompanying list of software and technology tools currently implemented by the employees, the auditor had enough information on hand to develop a list of semistructured KM questions to commence the interview process. Since management approved that only one week could be devoted to the data collection portion of the audit, an agile, flexible approach to inquiry was adopted and employee interviews were scheduled. Initial interviews occurred during Monday and Tuesday of the identified week; mid-week was reserved for the review of the auditor's notes; and follow-up interviews were scheduled for Thursday and Friday. The auditor projected that follow-up meetings would be required to request clarifications, verify previously collected data, and to solicit employee 'after-thoughts' for additional input. As everyone in the company was considered a stakeholder, Techbot's interview schedule (depicted in Table 3) included all personnel.

Table 3. Techbot's KM Audit Stakeholders and Interview(s) Schedule 


\section{Issues in Information Systems}

Volume 14, Issue 2, pp.233-252, 2013

\begin{tabular}{|c|c|c|c|}
\hline Techbot's Stakeholders & Schedul & Follow-Up & Type \\
\hline President & $1.5 \mathrm{Hrs}$. & 1 Hour & Solo Interview \\
\hline Security Officer & 1 Hour & 1 Hour & Solo Interview \\
\hline Controller & $1.5 \mathrm{Hrs}$. & 1 Hour & Solo Interview \\
\hline Program Manager & 1.5 Hrs. & 1 Hour & Solo Interview \\
\hline IT Manager & 4 Hrs. & 3 Hrs. & Solo Interview \\
\hline Contracts Manager & \multicolumn{2}{|c|}{ N/A } & Assumed Role of Auditor/Researcher \\
\hline Chief Engineer I & 1 Hour & 1 Hour & Solo Interview \\
\hline Chief Engineer II & 1 Hour & 1 Hour & Solo Interview \\
\hline Engineer Group I & $1.5 \mathrm{Hrs}$. & 1 Hour & Group - 3 Persons \\
\hline Engineer Group II & $1.5 \mathrm{Hrs}$. & 1 Hour & Group - 3 Persons \\
\hline Engineer Group III & 1.5 Hrs. & 1 Hour & Group - 3 Persons \\
\hline Technicians & 1 Hour & 1 Hour & Group - 5 Persons \\
\hline Totals & \multicolumn{2}{|c|}{30 Hours } & 21 Interviewees \\
\hline
\end{tabular}

The semi-structured questions posed by the auditor were designed to be inductive by nature, eliciting responses that represented the employees' perceptions, problems, issues, benefits, risks, and opinions regarding changes or improvements to the existing document system on the common drive (network server). Dependent upon the employee's current use of the system or individual needs for future applications, the conversation was permitted to take any direction the interviewee needed regarding this KM topic. Due to time constraints, not every question was posed to or addressed by every respondent; however follow-up interviews were scheduled to revisit areas of interest when an employee indicated she/he had more information to offer, or the auditor needed to clarify or verify previous notes. All interview notes were hand-written in journals and transcribed by the auditor in typed form.

All interviews were conducted in Techbot's conference room with only those scheduled present in the room. Snacks, bottled water, soft drinks, and coffee were provided in order to obtain maximum efficiency and comfort during the time allotted; and employees were asked to attend the interviews without cell phones, smart phones, pagers or laptops with the exception of the company President and the Security Officer whose positions required constant access to communication(s) equipment.

\section{Audit Results and Findings}

The interview data were rigorously analyzed, cross-checked, and the responses were sorted as trends within the four groups of employees: Management; Chief Engineers; Engineers; and Technicians. As patterns emerged the data were categorized to reflect the users' immediate concerns and needs regarding the current lack of a comprehensive and 'formal' records management and documentation control system. The audit results and findings were then documented and forwarded to the company President and the Board of Directors for review and consideration.

Data analysis resulted in the identification of the following topics of concern regarding the current 'informal' document system on the common drive (server): 1). Usage of the system; 2.) Routine access; 3). Filing and updating documents (version control); 4). Sharing documents (collaborating); and 5). Storing and maintaining documents. The results of the 'informal system' usage queries reflected that two groups, Chief Engineers and Engineers, reported similar practice and usage of the existing KM technology; and two groups, Management and Technicians, differed significantly in its practice and usage. Management recorded the highest level of use; the technicians recorded the lowest level of use; and the two groups of engineers consistently reported usage and access of the system relative to posting new information, but rarely utilized the common drive for anything else. Based upon the responses of individual employees, the usage levels of both management and engineers appeared to be consistent at $70-75 \%$. Relative to the 'informal documentation system,' the sharing and collaboration of information and documentation reported for all groups was low (recorded at 32\% or less); and routine access, filing, updating (version control), and storing and maintaining was less than $43 \%$ for the engineers. The technicians reported less than $25 \%$ utilization in all of the categories. These results are visually reflected in Figure 2. 


\section{Issues in Information Systems}

Volume 14, Issue 2, pp.233-252, 2013

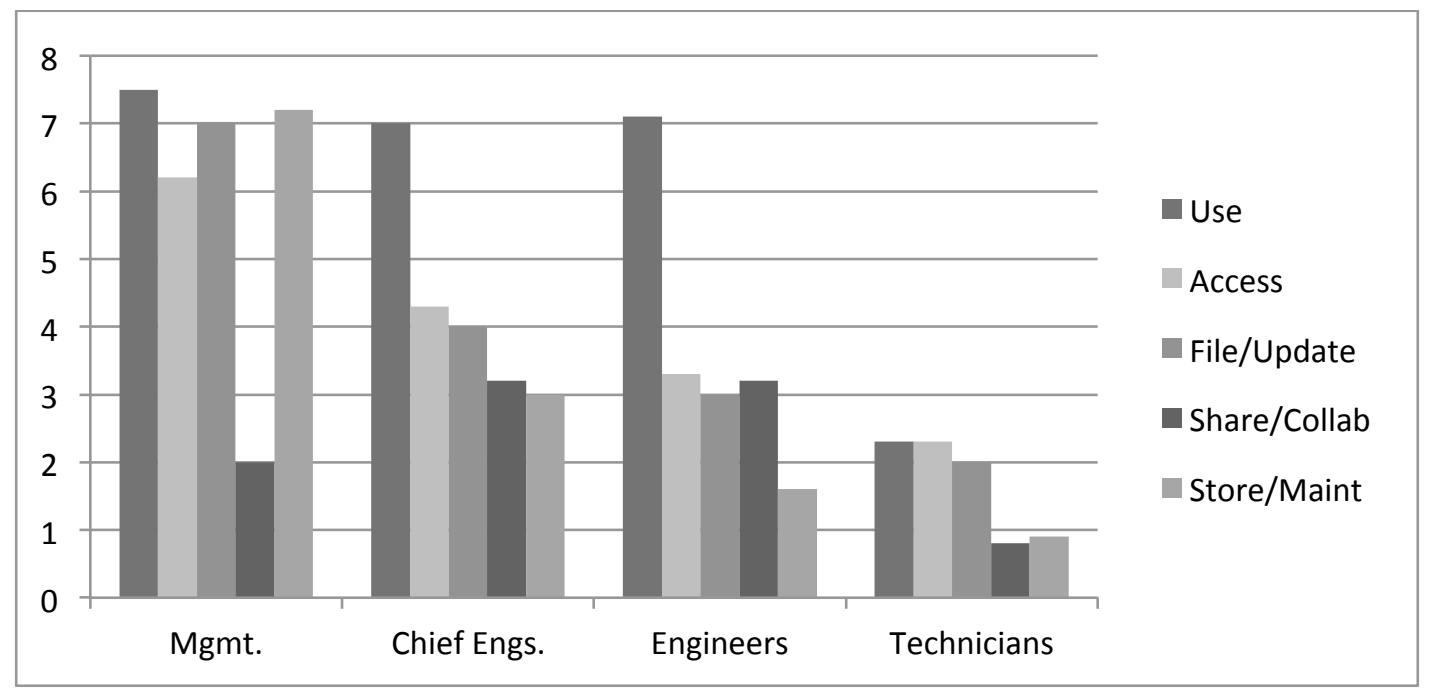

Figure 2. KM Audit Responses - Usage of the Current Documentation Control System (Calculated in \%s)

In summary, the audit found that the organizational members of Techbot differed in their use of the current documentation system in three ways: 1). Management made the most use of the current system, but neither collaborated with others nor shared their documents; 2). Chief Engineers and Engineers also had a high utilization relative to the posting of original documents, but rarely shared, collaborated, updated, or maintained their files; and 3). Technicians rarely accessed or used the current system.

\section{Discussion}

Overall, the data pointed to several key issues that could be favorably addressed with the implementation of a new records management and documentation control system. Table 4 illustrates the auditor's interview protocol of SemiStructured Interview Questions, and offers a sampling of some of the employees' responses.

Table 4. Auditor's List of Semi-Structured Interview Questions and Sampling of Employee Responses

\begin{tabular}{|l|l|}
\hline \multicolumn{1}{|c|}{ Semi-Structured Questions } & \multicolumn{1}{|c|}{ Samples of Employee Responses } \\
\hline $\begin{array}{l}\text { Do you use the common drive (server) to post, update, access, } \\
\text { maintain, and share documents? How do you use it --- for what } \\
\text { purposes? Please describe a typical event. }\end{array}$ & $\begin{array}{l}\text { "I don't post documents; I keep mine on my PC." } \\
\text { "I only post the documents that my manager directs me to. I do update } \\
\text { the versions of those documents." } \\
\text { "I post everything I develop on the common drive, but I password } \\
\text { protect my folders because I am afraid that someone will modify or } \\
\text { delete them." }\end{array}$ \\
\hline $\begin{array}{l}\text { How often do you use the common drive --- or ---why don't you use } \\
\text { it? }\end{array}$ & $\begin{array}{l}\text { "I use it daily to access my documents." } \\
\text { "I rarely use it because the info I need isn't there or it isn't available to } \\
\text { me." } \\
\text { "I can't open the folders." } \\
\text { "I used to look for HR information, but it never seems to be current." }\end{array}$ \\
\hline $\begin{array}{l}\text { When you use the common drive, how do you identify (name) your } \\
\text { documents and file folders? Is your naming process consistent or } \\
\text { random? Please cite an example. }\end{array}$ & $\begin{array}{l}\text { "I name my folders with the topic." } \\
\text { "My folders are named with my initials and dates." } \\
\text { "I use my own system or sometimes I use the customer project or } \\
\text { contract number." }\end{array}$ \\
\hline $\begin{array}{l}\text { How do you find information on the common drive? What is your } \\
\text { process? }\end{array}$ & $\begin{array}{l}\text { "I just start opening folders to look for the documents I need. } \\
\text { Sometimes the names on the folders don't really match the contents } \\
\text { and some of the folders are password protected and won't open. So I } \\
\text { move to the next folder or just give up and call someone for help." }\end{array}$ \\
\hline $\begin{array}{l}\text { What do you do when you cannot open a posted file folder? Who do } \\
\text { you contact for assistance? }\end{array}$ & $\begin{array}{l}\text { "I call the IT Mgr. to ask why I can't get into the folder. His typical } \\
\text { response is that I don't have administrator rights. He tells me to } \\
\text { contact the owner of the folder, but I usually don't know who that is." }\end{array}$ \\
\hline $\begin{array}{l}\text { Do you ever use 'workarounds' to access or create documents that } \\
\text { could be located on the common drive? Cite an example. }\end{array}$ & $\begin{array}{l}\text { "Yes. I use email as a workaround most often. I save all my emails and } \\
\text { so do my colleagues. We look for email attachments, use them, and } \\
\text { send them to each other." }\end{array}$ \\
\hline
\end{tabular}




\section{Issues in Information Systems}

\begin{tabular}{|c|c|}
\hline $\begin{array}{l}\text { Do 'workarounds' ever result in redundant tasks, tedious efforts, or } \\
\text { duplicate documents? Where do you store and maintain these 'work- } \\
\text { around' documents? Cite an example. }\end{array}$ & $\begin{array}{l}\text { "I suppose so. I keep the documents I need on email or my hard drive. } \\
\text { I have no idea if there are better or newer updates or templates. It's just } \\
\text { easier for me if I save them to my PC." }\end{array}$ \\
\hline $\begin{array}{l}\text { When you don't access the common drive for information, how do you } \\
\text { obtain what you need? How do you know that the data you receive is } \\
\text { the most current available? }\end{array}$ & $\begin{array}{l}\text { "I email another engineer or my manager to request the info/data. I use } \\
\text { whatever he sends but I never know if it is the most recent version. He } \\
\text { always tells me that it is the most recent info that he has on his PC." }\end{array}$ \\
\hline $\begin{array}{l}\text { Is the IT Manager available to meet your IT or KM needs? Is the IT } \\
\text { Manager cooperative and helpful? }\end{array}$ & $\begin{array}{l}\text { "The IT guy is usually too busy." } \\
\text { "He's arrogant. Says I won't understand the solution." } \\
\text { "It is easier and faster to find my own solution or just ask another } \\
\text { employee to show me what to do." } \\
\text { "The IT guy never smiles. He looks at me like I am too dumb to work } \\
\text { here." }\end{array}$ \\
\hline $\begin{array}{l}\text { Do you willingly share info/data with others? Do others willingly share } \\
\text { info/data with you? }\end{array}$ & $\begin{array}{l}\text { "I always send documents to anyone who asks, but getting anyone else } \\
\text { to respond to me is like pulling teeth." } \\
\text { "My engineering group shares documents, but we can't get info from } \\
\text { the other engineering groups." }\end{array}$ \\
\hline $\begin{array}{l}\text { Do you find that the info you need is already memorialized in writing } \\
\text { (documented) or do you need to visit or call someone to obtain the info } \\
\text { verbally? }\end{array}$ & $\begin{array}{l}\text { "Sometimes I meet with a colleague to get the info/data and I write } \\
\text { down what he tells me." } \\
\text { "I usually just walk over and ask someone for a document or an email, } \\
\text { but he usually tells me that he hasn't found the time to write the info } \\
\text { down." }\end{array}$ \\
\hline $\begin{array}{l}\text { Have you asked others to document and share the info that you and } \\
\text { others might need? What types of responses do you receive? }\end{array}$ & $\begin{array}{l}\text { "Yes, I've asked for it in writing, but I'm usually told the manager or } \\
\text { engineer hasn't gotten around to it yet." } \\
\text { "If it is not already written down when I ask for it, the typical answer } \\
\text { is that the person hasn't documented the data because he can't find the } \\
\text { time." }\end{array}$ \\
\hline $\begin{array}{l}\text { How would you like to see a 'formal' record management and } \\
\text { documentation control system unfold? Would it help you to have a } \\
\text { more efficient and accurate documentation control system? }\end{array}$ & $\begin{array}{l}\text { "I'll try a new system as long as it is easy to use and saves time." } \\
\text { "I think there should be a list of documents or a directory that could } \\
\text { help with searches." } \\
\text { "I don't want to waste time trying to open folders that are locked. They } \\
\text { should be kept in a separate place." }\end{array}$ \\
\hline $\begin{array}{l}\text { How do you feel about records management technology? Would you } \\
\text { use it? }\end{array}$ & $\begin{array}{l}\text { "Yes, I would like to see a better system for records management." } \\
\text { "If it doesn't take a lot of time to access it and find documents I need, I } \\
\text { would use it." }\end{array}$ \\
\hline
\end{tabular}

For instance, Management posts its documents, files, updates (version control), and maintains them but does not share them with anyone else. Most of the managers' file folders are password protected and the information is not available to anyone but the originator of the posting. Although Management often requires password protected files, it is unlikely that ALL of the files require this protection as the Controller, Program and Contracts Managers indicated they often need to access some of the data for financial, contracts, proposals and other external transmissions and deliverables to customers. A quick 'interim' fix of 'administrator' and 'read-only rights' may be able to resolve this area of concern on a case-by-case, as-needed basis.

The two Engineering groups also utilize the current system to post information, but the lack of routine access, updating, maintaining, and sharing/collaborating indicates that after posting the information, the data are continually worked 'exogenously' outside the system and updates, revisions, etc., are maintained on personal PCs and thumb drives. Data are occasionally shared with other engineers via email (and only upon request) with little or no version control, and generally unavailable to anyone else.

Responses from the five technicians indicated that they had little use for the common drive and infrequently interacted with the current system. Further probing by the auditor uncovered that they did not know what types of information were available to them (i.e., they didn't know what they were missing), such as corporate policies and procedures, HR info and related documents, templates, newsletters, brochures, engineering drawings and specifications, etc., because when information or a document was needed, a technician would ask a manager or engineer for the specific data and then received the info or document via email, again with no version control and often resulting in a redundant unnecessary task that could be remedied by a 'formal e-system' and/or 'database library' with version control.

In summary, the auditor recommended that specific employee KM issues be addressed by combining three actions to mitigate the existing problems and remedy the current documentation management system: 


\section{Issues in Information Systems}

- Create a corporate E-Library by replacing the current informal personal documentation management system with a KM technology product that is user-friendly, easy to maintain, efficient, collaborative, costeffective, and an obvious improvement over the existing common drive (network server) application.

- Once implemented, provide training to all 22 employees and incentivize them to use the new system. Incentives might include Lunch \& Learn training; and directly involve and assist the employees in their respective data transfer to the new system (to become familiar with and actually learn the process) with contests, games, rewards, prizes, and compensatory time off for extra effort. Also, tie routine utilization of the 'system' with an employee performance evaluation requirement, as well. Training will include instructions to a directory of how and where to find corporate documents and templates; a directory of personnel and their specific contact info and responsibilities; and an edict that all employees need to access the system first to locate information before contacting an individual for a specific 'workaround.'

- The corporate KM culture must embrace a new strategy of collaboration, trust, sharing, learning, and acceptance of the transfer of 'tacit' knowledge to 'explicit' knowledge. This new 'culture' will require a corporate 'champion' to oversee, support, and encourage the process through example (role model), actions, enforcement, and incentives. Additionally, the IT Manager needs to become more engaged, proactive, and visible in the process as an advocate, mentor, and advisor regardless of whether or not this person is named the Knowledge Champion.

These findings lend support to the auditor's arguments that organizational KM culture contributes to the use of technology (or lack of use) by various group subculture members. "Subcultures define norms in organizational units. A subculture that favors independence and individualism is less likely to promote conformity and cohesiveness among members ... than a subculture that promotes teamwork and cooperation" [21, p. 77]. Figure 3 depicts the interviewees' overall responses regarding their perceptions of the current corporate KM culture, reflecting that for the most part, knowledge is consistently hoarded by individuals; is often retained in 'tacit' form; and that employees often utilize KM 'workarounds' to avoid the current 'informal document system' and obtain information exogenously, even if it requires extra time and redundant work.

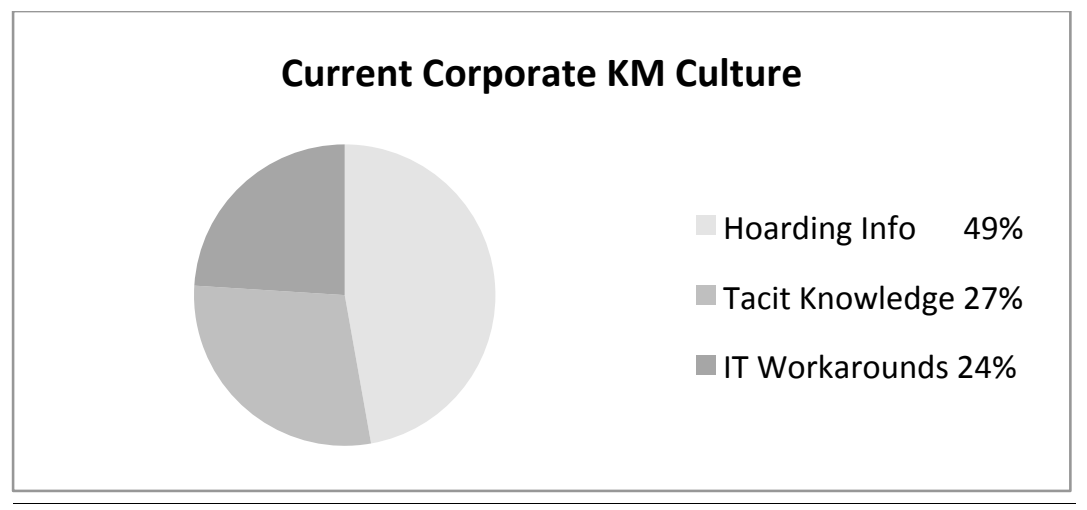

Figure 3. KM Audit Responses Regarding Perceptions of Corporate KM Culture

\section{Future Recommendations}

The results of this audit revealed that this company's current records management and documentation control system were greatly influenced by its corporate cultural foundation, the attitudes and perceptions of its employees, and a general lack of a well-defined KM strategy. Without the aegis of executive management support, a Knowledge (K) Champion or Advocate, and an engaged IT Manager, implementing change will be a serious challenge to the existing KM culture. Furthermore, it was apparent that the employees were dissatisfied with the current document repository on the server, minimally use it, or prefer to 'workaround' it entirely. A great deal of tacit knowledge exists at Techbot that needs to be documented, posted for access, and shared by others. Information hoarding must be abandoned, silos abolished to a practicable extent, and employees incentivized to share and collaborate. These 


\section{Issues in Information Systems}

changes all involve modifying the existing culture and the appointment of a $\mathrm{K}$ Champion to provide oversight and support.

Within the written report, the auditor recommended that Techbot invest in the implementation of a 'formal' erecords management and documentation control system, accompanied by employee training and incentive programs, and recommended three options to accommodate speedy implementation (summarized below).

- Internal Solution: Create a directory flat database and link the documents (records) to the 'directory' through a user interface in visual basic tied to an SQL database. This solution requires internal company IT expertise or a subject matter expert consultant.

- Off-the-Shelf Solution: Utilize an off-the-shelf type solution that will scan the server and create a search index. The device sits on the server and is only accessible internally. It can also be applied to search desktops and email. For example, a product entitled 'Google Enterprise Search' can be self-installed or a company representative will provide the service. Other vendors can be solicited for like or similar products.

- Documentation Control Software - Database Solution: Install a database like MS ${ }^{\circledR}$ SharePoint ${ }^{\circledR}$ or EMC Documentum $^{\mathbb{B}}$ and load all of the documents (objects) into the system for search, access, and updates. Identify the documents via key words, job numbers, or a company devised universal 'alpha-numeric' ID system. SharePoint ${ }^{\circledR}$ or Documentum ${ }^{\circledR}$ software product consultants will install the database, provide user manuals, and offer training and support services.

Management subsequently accepted the auditor's recommendations; selected the 'Documentation Control Software Database Solution' option; and the researcher received the approval to commence Phase III. Furthermore, Techbot's plans to change the philosophy of its corporate culture to one that ensures the best interests of people, processes, and technology intends to incorporate the theory that, "Organizational, cultural, and human factors lie at the heart of successful knowledge management sharing and transfer" [24, p. 175].

\section{PHASE III - THE SYSTEM BLUEPRINT AND IMPLEMENTATION}

Phases I and II, the KM SWOT and K Audit, respectively, set the stage for the integration of Phase III, the System Blueprint and Project Implementation. All efforts up to this point have led to the analysis of the current state of Techbot's corporate business intelligence; the identification of a high priority KM issue to be resolved; and the evaluation of the corporate culture as they all relate to 'people, processes, and technology' within the organization. Phase III selected a documentation control software product; developed a blueprint for project execution; and ultimately implemented and integrated the KM solution. The real intent was to create a comfortable learning environment in the workplace, enabling knowledge creation and collaboration, together with an evolving corporate culture built upon knowledge sharing and trust, not just a goal at Techbot, but a reality. Phase III began with the selection of a KM Team to assume the leadership and management roles for the System Blueprint and the Implementation Plan; and development of plans to deploy the 'hard' technology solution with the 'soft' solution of corporate culture modification.

\section{The KM Team}

The role of the KM Team was to build, implement, focus, and deploy Techbot's record management and documentation control technical solution. To ensure a successful project implementation within the constraints of budget and schedule: "The right blend of team members to lead this KM project clearly is a critical step" [35, $p$. 200]. The team was selected from disparate corporate disciplines, as the careful selection of personnel was critically important to ensure an appropriate balance and chemistry among the members. After careful deliberation, senior management designated the makeup of the KM Team and insisted upon a named Alternate (chosen by the representative of each discipline) to ensure that overall coverage of meetings and project deliverables were supported by a full complement of resources.

Tiwana [35, p. 200] suggested that "nontechnologists" are needed to augment the "technologists" (gurus and early adopters), because "they are the best people to gauge the possible usefulness of each feature that your system has [or needs]." Additionally, the functional representatives who serve and support all the company disciplines, such as Contracts, Procurement, Finance, Accounting, and Human Resources offer "laterality" to the Team as they can act 


\section{Issues in Information Systems}

Volume 14, Issue 2, pp.233-252, 2013

as a bridge between people from different backgrounds, skill areas, and specialties bringing a unique value to the team with the experience to deal with diverse issues rationally and creatively [35, p. 200]. These groups are often called "communities of practice because matrixed or multifunctional groups incorporate diverse viewpoints, age groups, and different roles, but whose overall common purpose is to add value" while serving all of Techbot by continuously improving the services they provide [35, p. 200-201]. Table 5 depicts Techbot's key KM Team representatives.

Table 5. Techbot's KM Team

\begin{tabular}{|l|l|}
\hline \multicolumn{1}{|c|}{ KM Team Member* } & \multicolumn{1}{c|}{ Role/Responsibility } \\
\hline Senior Executive Management: Techbot President & Corporate sponsor; visionary; commits resources and funding \\
\hline Team Leader/Project Manager & Dual leadership role; organizer; scheduler; manager; and motivator \\
\hline Information Technology (IT) Manager & Technology and implementation expertise \\
\hline $\begin{array}{l}\text { Business Community Stakeholders } \\
\text { - Contracts/Procurement } \quad \text { Finance/Accounting }\end{array}$ & Business expertise in specific areas \\
- Project Mgmt./Engineering & \\
\hline$\quad$ Quality Control/Environmental Health \& Safety & \\
\hline End-User Representatives (2 non-managerial users) & Functional expertise and user input \\
\hline Knowledge (K) Champion & Communicator; Activist (Selected from Team Members) \\
\hline *Responsibilities include naming an alternate to ensure representation & at meetings and support for project deliverables. \\
\hline
\end{tabular}

\section{KM System Blueprint and Project Implementation}

The first order of business for the KM Team was to understand the goal and mission of the project (as specified in Phase II); set the budget, milestones, and schedule; identify the high-risk areas and any cultural issues that need to be addressed; and from a variety of competitive choices, select the optimal software product for implementation. This first group effort signified the beginning of the System Blueprint and established the new tone of corporate culture, one of knowledge creation, sharing, and collaboration, set forth and led by example for the entire company by the KM Team.

The top priority of the Team Leader was to set forth and continually reinforce the project goal: Ensure that Techbot has a safe, secure, user-friendly efficient environment to electronically post, store, maintain, access, collaborate, and share information. Assuming the dual role of Project Manager, the Team Leader also emphasized that senior management empowered the Team to collectively select an optimal product to establish a formalized e-records management and documentation control system within the prescribed budget of $\$ 50,000$ and six month implementation schedule. The Team was immediately tasked to deliberate over the selection of a database product; and further reminded that the group's responsibility included not only the selection of a 'hard' technology solution, but also the development of a 'soft' solution to modify the corporate culture, as well.

\section{Selection of the Database: Microsoft ${ }^{\circledR}$ SharePoint ${ }^{\circledR} 2010$}

Several products were analyzed and competitively priced, but the Team ultimately chose the database product known as Microsoft ${ }^{\circledR}$ SharePoint ${ }^{\circledR} 2010$ to implement a formal e-records management and documentation control system. Table 6 illustrates Techbot's rationale for selecting MS $^{\circledR}$ SharePoint $^{\circledR} 2010$.

Table 6. Benefits of $\mathrm{MS}^{\circledR}$ SharePoint $^{\circledR} 2010$

- Meets the budget constraints of $\$ 50 \mathrm{~K}$ to purchase a Group License for 22 Users including an Annual Maintenance, Enhancements, and Upgrade Policy

- $\quad$ Product and company uses a Microsoft Server

- As an off-the-shelf product, SharePoint ${ }^{\mathbb{}} 2010$ requires little modification to meet the company needs

- Database software is also compatible with all other previously implemented Microsoft ${ }^{\mathbb{B}}$ Products

- SharePoint ${ }^{\mathbb{B}} 2010$ database can handle all types of non-MS documents with little or no modification

- Allows easy version control of documents

- Permits easy internal and external collaboration

- Allows for convenient storage of archival and historical documents

- User training can be performed in-house without the need to contract with external consultants

- Techbot's primary Federal Customer, the U.S. Navy, also uses SharePoint ${ }^{\mathbb{B}} 2010$ which will ensure an easy transition to document collaboration, version control, and timely submittal of contract deliverables 


\section{Issues in Information Systems}

Volume 14, Issue 2, pp.233-252, 2013

"Knowledge management is key to gaining core competitive ability" [37, p. 246].

\section{Project Rollout and Implementation}

Next the Team decided that a "Results-Driven Incremental Methodology (RDIM)" would be used for the six month rollout period because the "project can be broken up into a series of short fast-paced development cycles coupled with intensive implementation cycles, each of which delivers a measurable business benefit" [35, p. 277]. This means that as each discipline loads its data into SharePoint ${ }^{\mathbb{B}} 2010$, shortly thereafter all of Techbot can access, share, and collaborate with that specific data. By implementing "chunks [of data]" [35, p. 269], each department can determine and prioritize the documents to load into the system; purge the obsolete items; and store those that are to be maintained in historical archives. Rollout and integration of SharePoint ${ }^{\mathbb{B}} 2010$ can be easily phased per discipline without disruption of other departments or routine business; evidencing a more efficient and speedy return on investment (ROI) as the database system is incrementally integrated and implemented. It was further determined that no pilot testing of the system was required due to the familiarity with the product; the small user community; and the extensive training program planned.

\section{Employee Training Program}

Following the selection of the database and determination of the milestones and schedule, the development of an employee training program occurred next as it was to be concurrently integrated with the SharePoint ${ }^{\mathbb{R}}$ modules rollout. Since the majority of Techbot's employees are highly educated self-motivated autonomous knowledge workers in one-person departments, it was necessary to craft individualized training programs to ensure buy-in of the new database system. Davenport, Thomas, and Cantrell [7, p. 29] label this type of professional environment, "one-size-fits-one." Many creative options were considered but the Team ultimately decided upon the following scenario led by the IT Manager, as illustrated in Table 7.

Table 7. Techbot's MS ${ }^{\circledR}$ SharePoint ${ }^{\circledR} 2010$ Training Program

- $\quad$ Provide One Personalized Two-Hour Training Session for each end-user (and as needs dictate, for each new hire) prior to the loading/purging of documents to the database for each discipline

- Establish a Support System through an informal 'Help Desk' manned by the IT Manager; Rotate others to man the Help Desk, support the IT Manager, and learn the system

- Provide continuous training through monthly 'Lunch and Learn' sessions for six months following full implementation; and quarterly thereafter for system updates, upgrades, and training required for changes to policies and procedures

- Develop "Techbot e-Records Management and Documentation Control Policies, Procedures, and User Guidance" and post on SharePoint ${ }^{\circledR} 2010$ for companywide access

\section{Techbot's KM Employee Incentive Program}

One of the key roles of the Knowledge Champion was also to introduce and rollout the "KM Employee Incentive Program" to motivate and encourage immediate use of the system, codify tacit knowledge to explicit information, and to provide rewards to those that embrace the new culture of knowledge sharing, collaboration, and "continuous change as a normal part of work life" [35, p. 284]. "Successful KM initiatives require appropriate incentives for team members and a user-friendly information system that facilitates the sharing and management of knowledge among all project participants" [1, p. 165). Lucas [22, p. 428] advocates that, "Before we adopt new ways of doing things, we establish appropriate rewards for employees who help to implement the changes." Table 8 describes the primary benefits of Techbot's "KM Employee Incentive Program."

Table 8. Techbot's KM Employee Incentive Program

Techbot offered rewards and benefits to those that proactively assisted the company in obtaining its Knowledge Management (KM) goals. A sampling of its KM programs involved the following performance criteria:

- Mentor new and junior employees; share academic, historical, and customer knowledge and insight

- Codify specific tacit knowledge; build repositories; and post information to the database as explicit knowledge

- $\quad$ Post document templates and updated versions to the database; Include user guidance for easy access

- $\quad$ Support IT 'Help Desk' by learning the new “e-Records Management and Documentation Control System” $\left(\right.$ MS $^{\circledR}$ SharePoint $^{\circledR} 2010$ database); Volunteer to routinely rotate at the 'Desk' to provide IT support

- Collaborate on proposal projects as Team Members; Reuse document templates; Post new proposal templates for future use

- Write and submit 'good news' success stories for consideration and posting to the database

Depending upon the scope of each KM effort, Techbot awarded the following employee incentives: 


\section{Issues in Information Systems}

- $\quad$ Gift Cards, Certificates of Achievement; Plaques

- $\quad$ Bonuses, Salary Increases

- Opportunities for Leadership Roles and Promotions

- $\quad$ Cash Incentives thru Outstanding Annual Performance Reviews

- Compensatory Time-Off for Special Efforts or Successful Projects

- Employee of the Month designated Parking Space (in front of the building under awning cover)

- $\quad$ Registrations for Professional Conferences, Including Travel Expenses

\section{Measuring Success: Leading and Lagging Indicators}

Equally important was the necessity for the Team to measure and report upon the success of its KM initiative. The Team Leader determined that leading and lagging indicators, 'soft' measurements before economic data was available and 'hard' statistics to report 'after the fact' [3;23], respectively, would be analyzed and reported to senior management. The following elements were observed, recorded, measured, and reported to evaluate Techbot's SharePoint ${ }^{\circledR} 2010$ usage. Table 9 illustrates and compares the results of Techbot's leading and lagging indicators.

Table 9. Techbot's KM Project Leading and Lagging Indicators

\begin{tabular}{|c|c|}
\hline $\begin{array}{l}\text { Leading Indicators ('Soft'): } \\
\text { Measured at Midpoint (3 Months) and Endpoint (6 Months) of the } \\
\text { System Implementation and Integration }\end{array}$ & $\begin{array}{l}\text { Lagging Indicators ('Hard'): } \\
\text { Measured a Full } 6 \text { Months Following the Completed } 6 \text { Months of } \\
\text { System Implementation and Integration }\end{array}$ \\
\hline - $\quad$ Increased system utilization (via Time/Date Stamp) & $\begin{array}{l}50 \% \text { More proposals submitted to customers (due to document } \\
\text { templates reuse) }\end{array}$ \\
\hline $\begin{array}{ll} & \text { Increased user confidence due to training \& IT Help Desk } \\
\text { rotation system }\end{array}$ & Proposal win rate increased by $36 \%$ \\
\hline $\begin{array}{l}\text { Decreased frustration as documents were located and reused } \\
\text { (time saved and less customer hours billed for rework) }\end{array}$ & $\begin{array}{l}\text { R\&D patents management established successfully; Collection } \\
\text { of royalties and license fees increased by } 28 \%\end{array}$ \\
\hline $\begin{array}{l}\text { - Increased participation (Sign-Ups) for the KM Employee } \\
\text { Incentive Program }\end{array}$ & $\begin{array}{l}\text { - Annual budget of } \$ 2,500 \text { for users' incentives and rewards for } \\
\text { users depleted after first six month period due to successful } \\
\text { system usage }\end{array}$ \\
\hline $\begin{array}{l}\text { Improved overall group camaraderie due to collaboration, } \\
\text { teamwork, sharing; Employees also enjoyed the competitive } \\
\text { rivalry while working to achieve rewards and incentives }\end{array}$ & $\begin{array}{l}\text { Time (labor) recorded to the database project charge code } \\
\text { incurred by the KM Team for employee training and problem } \\
\text { resolution decreased by } 63 \% \text { following the establishment of } \\
\text { the IT Help Desk employee rotation system }\end{array}$ \\
\hline
\end{tabular}

\section{KM System Usage: Enforcement and Consequences}

The KM Team convinced senior management that more than short-term employee incentives and rewards were required to maintain long-term commitments to the new e-Records Management and Documentation Control System, therefore, the Team recommended that all annual employee performance reviews include a specific line item to evaluate the employee's usage of the SharePoint ${ }^{\circledR} 2010$ database. A percentage of the entire employee review (determined by each group's supervisor or manager in conference with the K Champion) was allocated to a special KM line item to be reflected in the overall employee salary, raise, bonus, and/or potential promotion opportunities. Additionally, it was determined that the employee incentives, rewards, and acknowledgements will cease if database usage declines. The $\mathrm{K}$ Champion was tasked to consistently communicate this message to Techbot's employees, and senior management agreed to enforce the consequences.

\section{MODIFYING THE CORPORATE CULTURE}

As corporate culture is a construct and an intangible 'soft' social science that influences organizational behavior, the team recognized that more research and understanding in this area was required in order to secure employee buy-in to the new system and complete a successful KM mission for Techbot. For example, "The social side of a relationship ... often determines whether someone will respond readily and helpfully to a request . . . and high performers seem to have a natural ability to find points of commonality with others" [3, p. 20]. However, "every knowledge-based organization . . . wastes time, money, and human energy re-creating intellectual assets [indicating that companies do not do a good job of] exploiting the intellectual assets they have already created" [8, p. 13]. But why does this appear to be a systemic problem within entities, regardless of organizational size? An exploration of organizational (corporate) culture research and business management theories provided insightful information toward understanding this phenomenon. 


\section{Issues in Information Systems}

"Culture constitutes the general framework in which company strategy in relation to KM is established. . . [It] influences ... work autonomy, motivation, and decision-making systems . . . [affecting the way] knowledge is gathered [and shared]" [9, p. 91]. Organizational culture is ingrained and inured based upon corporate practices, such as the adoption of heroes, rituals, and symbols, that are learned and relearned as one changes employment or careers; unlike national or family culture that is based upon values inherent from birth, childhood, ethnicity, religion, and school. Business management theorists, Hofstede, Hofstede, and Minkov [14], addressed this intangible glue of culture arguing that an individual's national and family values are entrenched at the core, but that the organizational practices of heroes, rituals, and symbols can be peeled away, modified, and changed. Harrison [12, p. 28] depicted an open system organization enveloped by a cultural environment with constantly flowing throughputs of behavior, processes, and technology (Figure 4), a likely receptive candidate for KM implementation.

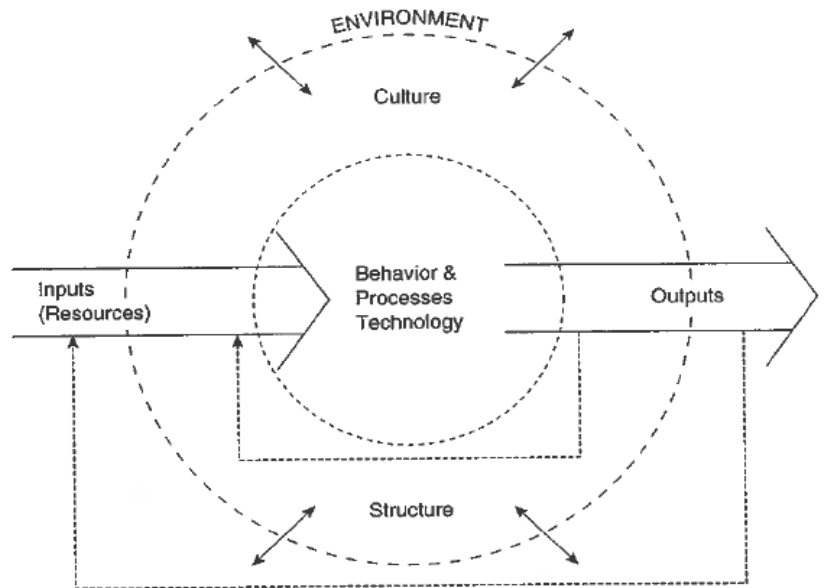

Figure 4. Organization as an Open System [12, Fig. 2.1, p. 28]

Subject matter experts Davenport, DeLong, and Beers [4, p. 50] reported that eight key elements are essential to realize a successful KM project. These key discriminators (listed below) were well-aligned with the cultural gaps evidenced at Techbot and contributed to the Team's development of a cultural roadmap that embraced technology innovation.

- Senior Management Support

- Clear Purpose and Language

- Flexible Knowledge Structure

- Knowledge Friendly Culture

- Motivational Practices

- Economic Performance/Value

- Technology and Organizational Infrastructure

- Multiple Channels for Knowledge Transfer

Furthermore, Davenport, Harris, DeLong, \& Jacobson [5, p. 118] argued that the "human realm" cannot be ignored during the implementation of KM initiatives, as "organizational, cultural, and strategic changes [are] necessary to leverage their investments." To emphasize this point, the authors characterized organizational and corporate culture as equivalents to technology and data, strategy, skills, and experience embedded within the foundation of a successful KM project, as depicted in Figure 5. 


\section{Issues in Information Systems}

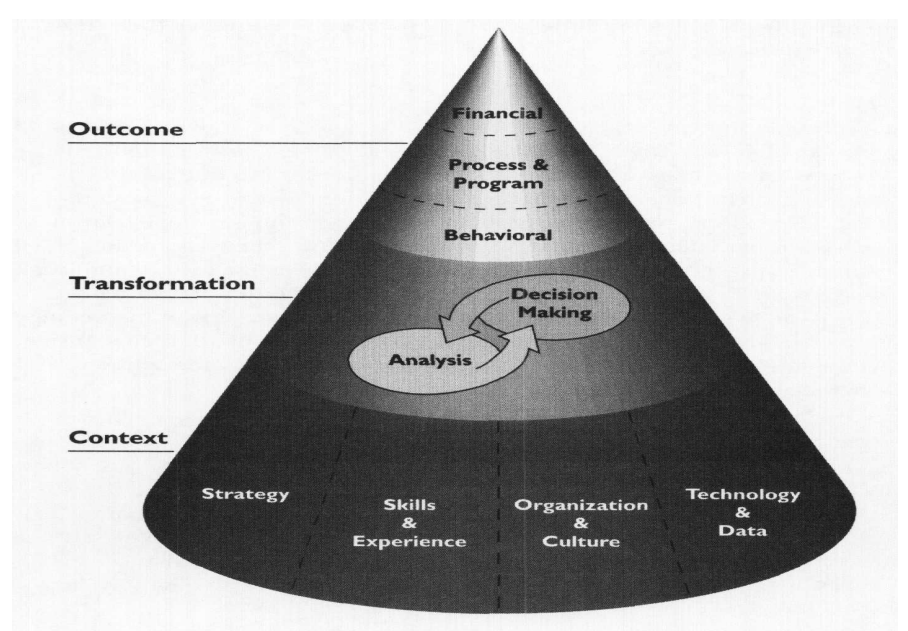

Figure 5. "Data to knowledge to results" [5, p. 121]

Techbot's KM Team also recognized that the current corporate culture needed to hear one unifying voice to assist the employees with accepting the new KM initiative and to ensure user buy-in and routine use. Therefore, a wellliked and respected senior (but not Chief) engineer was appointed from within the Team as the Knowledge Champion to communicate a clear and consistent message of a knowledge friendly culture; and to explain the expectations and rationale for implementing a formal database system. Additionally, the Champion was tasked to discourage information silos, technology workarounds, and personal knowledge management systems; motivate and encourage users; and generally be a database activist. Codifying tacit knowledge to explicit documentation was also a primary concern for the Champion as well, because "to express the silent side of what we know is a difficult chore" [34, p. 258] and requires special attention. Equally important was communicating a message of trust to help eliminate fear of loss of employment or job obsolescence due to technical innovation. "A culture of mutual trust ... encourages team members to depend on one another ... thus increasing the likelihood that they will communicate openly and effectively to achieve their shared goals" [1, p. 165].

\section{CONCLUSIONS}

"KM and business strategy must drive each other. Creativity without strategy is called art, creativity with strategy is called good design" [35, p. 120]. Converting individual knowledge into organizational knowledge is no easy task, but Techbot is now positioned to embrace its KM strategy permitting it to evolve as the company grows in employee size, revenue, and project complexities. The completion of this KM study resulted in the overarching responses to the original RQs as summarized below.

RQ1: How does a small entrepreneurial technology firm of subject matter experts (SME) efficiently implement a cost-effective influential KM Program?

The objective of this research was to observe the practices and interview the employees of a small boutique R\&D technology company through an efficient short-term three-phased approach: 1. Perform an Organizational and technology SWOT analysis; 2. Perform a Knowledge Audit to isolate an issue of interest or problem area; and 3. Develop a System Blueprint and Implementation Plan to research and identify a solution and fix the problem. Essential keys to success were: Senior management sponsorship and support; Employee teamwork and buy-in; Short-term agile flexible KM approach to maintain interest and visibility; and appointment of a Team Leader or Project Manager (PM) to maintain costs, scope, and schedule parameters.

RQ2: Why were these KM measures taken, certain decision made, and what was the result?

Techbot's implementation of the Microsoft ${ }^{\circledR}$ SharePoint ${ }^{\circledR} 2010$ e-Records Management and Documentation Control System resulted in a highly successful KM project following its six month rollout and training period (on time and within budget). It took a great deal of commitment from Techbot's senior management, the KM Team, the Team Leader (PM), the K Champion, and all the end-users of Techbot to focus on a common project goal: Enable users to 


\section{Issues in Information Systems}

easily and efficiently store, maintain, access, update, use and share information. Furthermore, it took technology know-how, leadership, discipline, communication, politics, economics, decision support, training, incentives, creativity, change management, conflict resolution, and a change of corporate culture to establish a learning environment where codifying tacit to explicit knowledge, collaboration, sharing, documenting, and knowledge creation was the norm. In short, it took 'people, processes, technology' and a fourth attribute, 'corporate culture' working together to ensure the success of this KM initiative.

Liebowitz [17, p. iii] argued that "[k]nowledge management deals with the process of creating value from an organization's intangible assets." Ross [33, p. 208] suggested that the "complexity of the human factors is harder to manage than the technology (the tech is the easy part)," but it's not an impossible feat. The trick is to merge two disparate philosophies that typically conflict: the "technoliterate users" and early adopters who embrace change and exploration; and the "technophobic users" [35, p. 282] who resist change and adapt slowly, into a comfortable corporate culture that suits the majority and encourages outliers to join. "Sharing resources is a necessary condition for creating synergy" [35, p. 283]; and "change[ing] corporate culture from that of defensive knowledge hoarding to a knowledge-sharing one ... requires strong incentives and the eliminations of related risks" [35, p. 294]. Techbot learned to evolve and accept a corporate culture that used innovative technology routinely, accepted iterative improvements, and embraced an intuitive agile KM process as a matter of course.

Now Techbot has to face the real challenge of continuing its KM success: to embrace future iterative improvements; to monitor usage; to encourage and motivate greater access and collaboration; to resist the urge to regress to prior knowledge hoarding and tacit habits; to foster learning and educational opportunities; and to reward mentors, leaders, and early adopters. In recognition of its firm commitment to people, processes, technology, and culture, perhaps Techbot will consider pursuing the next step in its KM evolution by naming a Chief Knowledge Officer (CKO) to propel and expand the momentum. One hopes that Techbot will continue its economic investment, renewal, and reuse of KM assets; ever wary of the day "when a product's life cycle whispers hints of obsolescence, loss of competitive advantage, or depletion of value" [8, p. 15]; and always ready to embark upon a new KM solution.

\section{REFERENCES}

1. Ajmal, M., Helo, P., \& Kekäle, T. (2009). Critical factors for knowledge management in project business. Journal of Knowledge Management, 14(1), 156-168.

2. Cooper, R. B. (1994). The inertial impact of culture on IT implementation. Information Management, 27, 17-31.

3. Cross, R., Davenport, T. H., \& Cantrell, S. (2003). The social side of performance. MIT Sloan Management Review, 45(1), 20-22.

4. Davenport, T. H., De Long, D. W., \& Beers, M. C. (1998). Successful knowledge management projects. Sloan Management Review, 39(2), 43-57.

5. Davenport, T. H., Harris, J. G., De Long, D. W., \& Jacobson, A. L. (2001). Data to knowledge to results: Building an analytic capability. California Management Review, 43(2), 117-138.

6. Davenport, T. H., \& Prusak, L. (2000). Working knowledge: How organizations manage what they know. Cambridge, Massachusetts: Harvard Business School Press.

7. Davenport, T. H., Thomas, R. J., \& Cantrell, S. (2002). The mysterious art and science of knowledge-worker performance. MIT Sloan Management Review, 44(1), 23-30.

8. Davenport, T. H., Thomas, R. J., \& Desouza, K. C. (2003). Reusing intellectual assets. Industrial Management, 45(3), 12-18.

9. Donate, M. J., \& Guadamillas, F. (2010). The effect of organizational culture on knowledge management practices and innovation. Knowledge and Process Management, 17(2), 82-94.

10. Gloet, M. (2002). Knowledge management audit: The role of managers in articulating and integrating quality practices. Managerial Auditing Journal, 17(6), 310-316.

11. Hall, E. T. (1990). The silent language. New York: Anchor Books. (Original work published 1959)

12. Harrison, M. I. (2005). Diagnosing organizations: Methods, models, and processes. Thousand Oaks, CA: SAGE Publications, Inc.

13. Henczel, S. (2001). The information audit as a first step towards effective knowledge management. Information 


\section{Issues in Information Systems}

Outlook, 5(6), 48-62.

14. Hofstede, G., Hofstede, G. J., \& Minkov, M. (2010). Cultures and organizations: Software of the mind. New York, NY: McGraw-Hill.

15. Larman, C. (2004). Agile and iterative development. Boston, MA: Addison-Wesley.

16. Levy, M., Hadar, I., Greenspan, S., \& Hadar, E. (2010). Uncovering cultural perceptions and barriers during knowledge audit. Journal of Knowledge Management, 14(1), 114-127.

17. Liebowitz, J. (Ed.). (1999). The knowledge management handbook. Boca Raton, FL: CRC Press.

18. Liebowitz, J. (2003). A knowledge management implementation plan at a leading US technical Government organization: A case study. Knowledge and Process Management, 10(4), 254-259.

19. Liebowitz, J. (2006). What They Didn't Tell You about Knowledge Management. Lanham, MD: SCARECROW PRESS, INC.

20. Liebowitz, J., Rubenstein-Montano, B., McCaw, D., Buchwalter, J., Browning, C., Newman, B., Rebeck, K., \& RWD Technologies Inc. USA Knowledge Management Methodology Team. (2000). Case study: The knowledge audit. Knowledge and Process Management, 7(1), 3-10.

21. Lin, C., \& Ha, L. (2010). Subculture, critical mass, and technology use. Journal of Computer Information Systems, 50(3), 72-80.

22. Lucas, L. M. (2010). The role of teams, culture, and capacity in the transfer of organizational practices. The Learning Organization, 17(5), 419-436.

23. Manuele, F. A. (2009). Leading \& lagging indicators: Do they add value to the practice of safety? Professional Safety, December, 28-33.

24. Mignon, S., \& Janicot, C. (2009). Knowledge use, capitalization and sharing in the audit and consultancy professions. Knowledge and Process Management, 16(4), 174-185.

25. Năstase, P., Stoica, D., Mihai, F., \& Stanciu, A. (2009). From document management to knowledge management. Annales Universitatis Apulensis Series Oeconomica, 11(1), 325-334.

26. Nonaka, I. (1995). The knowledge creating company. New York, NY: Oxford University Press, Inc.

27. Nonaka, I. (2000). The knowledge-creating company. Harvard Business Review, 11-12, 96-104.

28. Nonaka, I., \& Konno, N. (1998). The concept of " $B a$ ": Building a foundation for knowledge creation. California Management Review, 40(3), 40-54.

29. O'Dell, C., \& Hubert, C. (2011). The new edge in knowledge: How knowledge management is changing the way we do business. Hoboken, NJ: John Wiley \& Sons, Inc.

30. Petrides, L., McClelland, S., \& Nodine, T. (2004). Costs and benefits of the workaround: Inventive solution or costly alternative. The International Journal of Educational Management, 18(2/3), 100-108.

31. Polanyi, M. (1958). Personal knowledge: Towards a post-critical philosophy. Chicago, IL: Chicago Press.

32. Polanyi, M. (1962). Tacit knowing: Its bearing on some problems of philosophy. Reviews of Modern Physics, 34(4), 601-616.

33. Ross, M. (2004). Fables and facts. In R. Kimball, \& M. Ross (Eds.), The Kimball Book Reader (pp. 204-208). Indianapolis, IN: Wiley Publishing, Inc.

34. Skovira, R. J. (2007). Ontological grounding of a knowledge mapping methodology: Defining data, information, and knowledge. Issues in Information Systems, 8(2), 258-264.

35. Tiwana, A. (2002). The knowledge management toolkit: Orchestrating IT, strategy, and knowledge platforms ( $2^{\text {nd }}$ ed.). Upper Saddle River, NJ: Prentice Hall.

36. Turban, E., Sharda, R., Delen, D., \& King, D. (2011). Business intelligence: A managerial approach (2 ${ }^{\text {nd }}$ ed.). Upper Saddle River, NJ: Prentice Hall.

37. Wang, J., \& Xiao, J. (2009). Knowledge management audit framework and methodology based on processes. Journal of Technology Management, 4(3), 239-249.

38. Yin, R. K. (2009). Case study research (4 ${ }^{\text {th }}$ ed.). Thousand Oaks, CA: SAGE Publications, Inc. 